\title{
Evidence for Niche Differences in Sympatric Populations of Cerastoderma edule and C. lamarcki
}

\author{
V. Brock \\ Institute of Ecology and Genetics, University of Aarhus, DK-8000 Aarhus C, Denmark
}

\begin{abstract}
Yearly growth rates of a single year class of co-existing cockles Cerastoderma (Cardium) edule (L.) and C. lamarcki (Reeve) show interspecific differences. Differences in habitat conditions influence growth rates of the two species differently at the two Danish fjord localities compared. At the Aggersborg locality, the two species grow at similar rates, while habitat conditions at the Langerak locality cause faster growth of $C$. edule, but slower growth of $C$. lamarcki. Habitat niche dimensions of the two species are thus demonstrated to be different.
\end{abstract}

\section{INTRODUCTION}

Growth rates of cockles have been demonstrated to vary according to different factors such as temperature, salinity and food availability (Thamdrup, 1935; Kreger, 1940; Smidt, 1951; Kristensen, 1957; Eisma, 1965; Riva, 1976; for pertinent reviews consult 'Marine Ecology', Volume I: Kinne 1970, 1971, 1972). A comparison between growth rates of the two species Cerastoderma edule and $C$. lamarcki therefore requires that environmental conditions be identical for both species; this is the case where they occur in sympatry. Such comparison may reveal whether both cockles are equally adapted to the habitat concerned.

Identical growth rates of the two species may result from complementary gains due to different environmental factors and thus do not necessarily reflect identical niches. In contrast, differential growth rates in similar habitats constitute positive evidence for different niches.

It has previously been demonstrated that allopatric Cerastoderna lamarcki, (named Cardium glaucum) from a variety of different European localities grow markedly slower than allopatric $C$. edule (Brock, 1979a). Measurements of cockles from the collections of the Zoological Museum, Copenhagen - derived from Northren European and some Mediterranean localities - confirm this, although C. glaucum grow relatively fast at some other Mediterranean localities (Høpner Petersen, personal communication). However, a comparison between different year classes of sympatric $C$. edule and $C$. lamarcki from different localities seemed to suggest similar growth rates (Brock 1979a); this is also in accordance with the growth of the two species in sympatry found in the Kysing Fjord (Muus, 1967). In the present paper a more detailed analysis of the growth of single year classes at successive ages is described for sympatric populations.

\section{MATERIALS AND METHODS}

1975-year-class cockles were sampled at about $1.5 \mathrm{~m}$ depth from two localities in the Limfjord, Aggersborg and Langerak (Denmark), in spring 1977, in spring, summer and autumn 1978 and in spring 1979 (Fig. 1). Both localities are constantly submerged and tidal influence is negligible. (Hylleberg et al., 1978). Random samplings showed the densities to be low: at Aggersborg $<1 \mathrm{~m}^{-2}$, at Langerak: $10-50 \mathrm{~m}^{-2}$. Individuals were located by their siphon openings at the bottom surface and sampled by means of a sieve with a long handle or by hand while diving.

Cockles were identified by means of electrophoretical patterns (MdH) (Brock, 1978) as Cerastoderma lamarcki in line with recent immunoelectrophoretical studies of Cardium systematics (Brock, in prep.). Age determination was based on winter rings (Orton, 1926), supported by polished shell sections (Jones et al., 1978). The age determination is illustrated in Figure 2. 

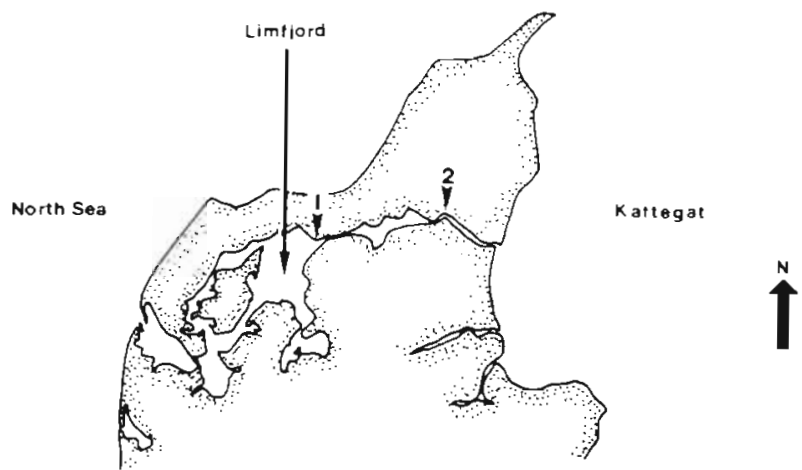

Fig, 1. Northern part of Jylland (Denmark) with the two Limfjord localities, 1: Aggersborg; 2: Langerak

Dry weight analysis was carried out as described by Hylleberg et al. (1978)

The length of the shell enclosed by a winter ring was measured with sliding calipers to the nearest $0.5 \mathrm{~mm}$. and the length of the shell to the nearest $0.1 \mathrm{~mm}$.

Bertalanffy's (1957) model of growth: $l_{t}=L_{\infty}$ $\left(1-e^{-k}\left(t-t o^{\prime}\right)\right.$ was used to describe the growth rates of each individual. Based on the $K$ and $L_{\infty}$ values calculated for each year class of four year old cockles, the expected lengths of each age for both species at the two localities were calculated; $t_{0}$ was chosen to fit the growth curve to mean lengths observed in the first growth season.

\section{RESULTS}

Few cockles reached the age of four growth seasons, especially so in the Aggersborg locality. Figures 3 and 4 show the observed mean lengths related to Bertalanffy's model of growth (1957); for details see Table 1.

Figures 3 and 4 illustrate observed mean lengths (symbols) and growth curves according to Bertalanffy's growth model, based on mean lengths.

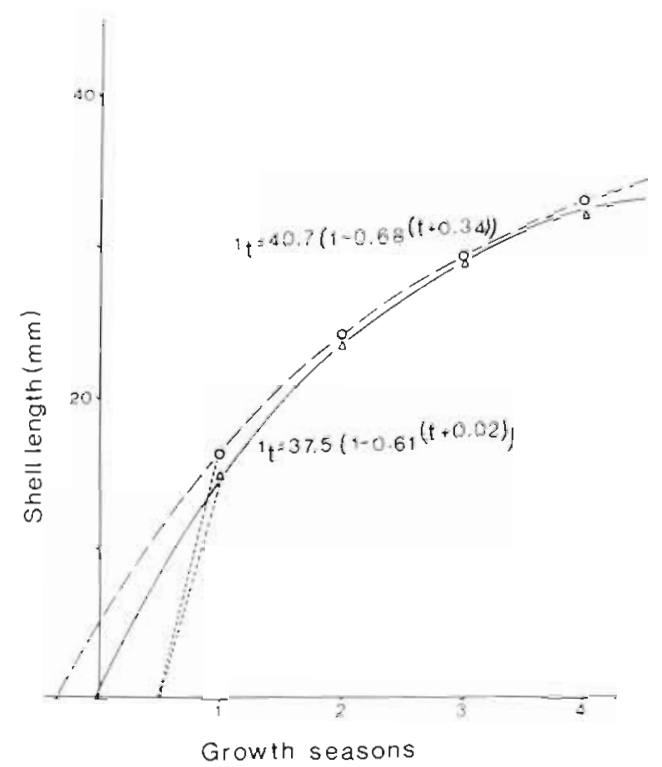

Fig. 3. Cerastoderma edule (o) and C. lamarcki ( $\Delta$ ). 1975-year class from Langerak. Sizes at successive ages of these cockles are used for calculations of the growth curves shown. Growth model of Bertalanffy: $\frac{d l}{d t}=K\left(L_{\infty}-1\right)$. Symbols; observed mean sizes for each year class

As evident from Table 1 and Figures 3 and 4, Cerastoderma edule grows faster at Langerak than at Aggersborg from the $1^{\text {st }}$ to the $4^{\text {th }}$ growth season, whereas C. lamarcki grows slower at Langerak than at Aggersborg within the same period. The $L_{\infty}$ values obtained by the growth model applied to the observed mean values (Table 1 ) suggest that $C$. edule may become larger at Langerak than at Aggersborg. The growth of the two species is quite similar at Aggersborg, but different at Langerak.

The relation between individual $L_{\infty}$ to $K$ values estimated from $l_{t+1}-l_{t}=\left(L_{\infty}-l_{t}\right)\left(1-e^{-k}\right)$ shows interspecific differences at both localities with respect to the four

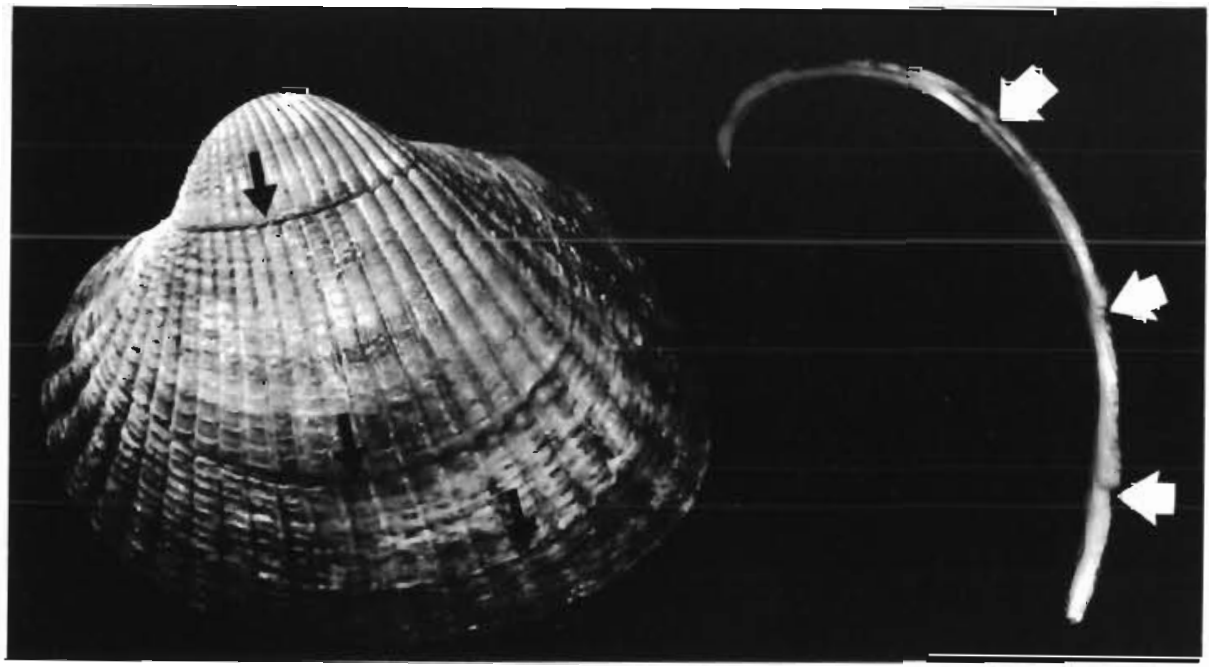

Fig. 2. Cerastoderma edule. Winter rings (arrows) on 4-growth-season old individuals; shell (left) and polished shell section (right) 


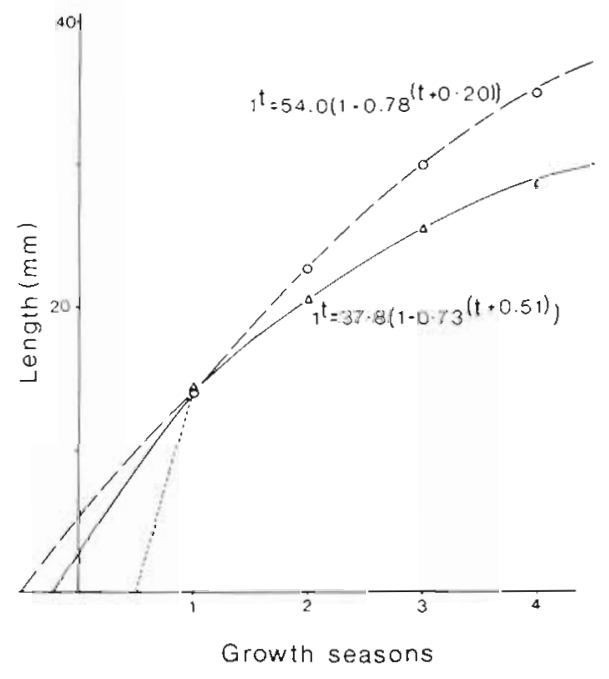

Fig. 4. Cerastoderma edule (o) and C. lamarcki ( $\Delta$ ). 1975-year class of individuals from Aggersborg. For explanation see legend to Figure 3

year-class group (Figs 5 and 6); this is also the case for the three year-class group at Langerak (Fig. 7), but not at Aggersborg (Fig. 8). The differences found are even more pronounced when dry weight is considered, since Cerastoderma edule is heavier than $C$. lamarcki of similar length (Fig. 9).

\section{DISCUSSION}

For cockles, the most meaningful measure of size is the weight of metabolizing soft tissues. However, since it is impossible to measure directly the weight of the cockle at earlier life stages, length was chosen instead. A linear relation (double logarithmic scale) between shell length and dry weight of soft tissue was found (Fig. 9) in accordance with the expected linear relation between the cube of length and of tissue volume. Shell length is therefore considered an acceptable measure for size and growth.

A comparison between length and age of the four year classes of both species from the two investigated localities yields results which are within the range of the values found by different authors (Boyden, 1972).

Interspecific differences of individual growth rates are documented by differences obtained for the relation between the two characteristic parameters from the growth equation, $L_{\infty}$ and $K$ (Figs 5, 6, 7 and 8). Interlocality differences are expressed by different individual relations for 4-year old Cerastoderma lamarcki at the two localities studied (Figs 5,6). Values for $L_{\infty}$ and $K$ were obtained under certain habitat conditions concerning space and time and hence should be interpreted in this context.

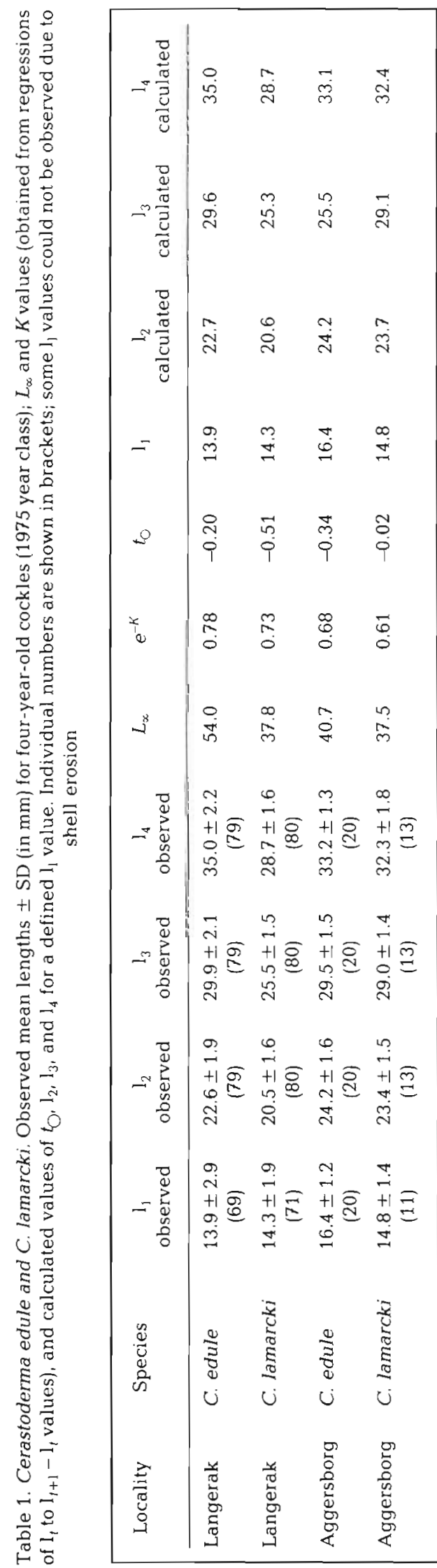




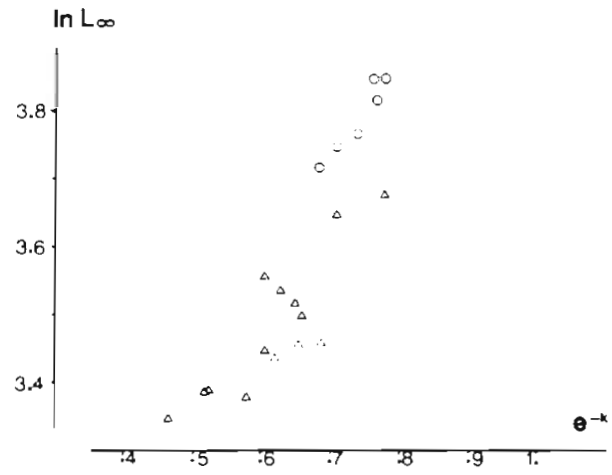

Fig. 5. Cerastoderma edule (0) and C. lamarcki ( $\triangle$ ). The $\ln L_{\infty}$ to $e^{-K}$ relation for four-year-old cockles; 1975 -year class at Langerak

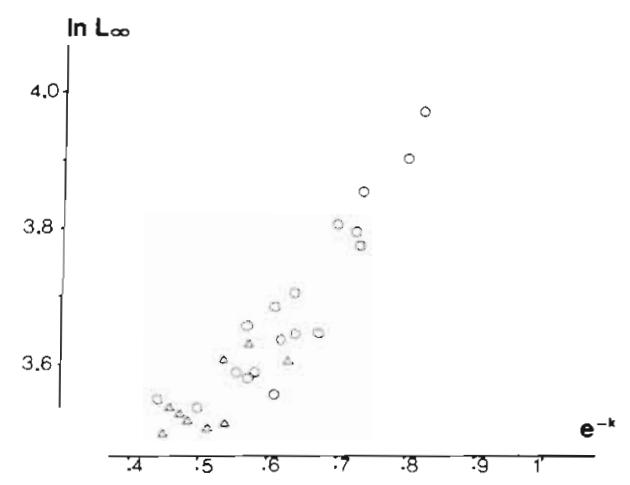

Fig. 6. Cerastoderma edule (oland C. lamarcki (A). The In $L_{\infty}$ to $\mathrm{e}^{-\kappa}$ relation for four-year-old cockles; 1975 -year class at Aggersborg

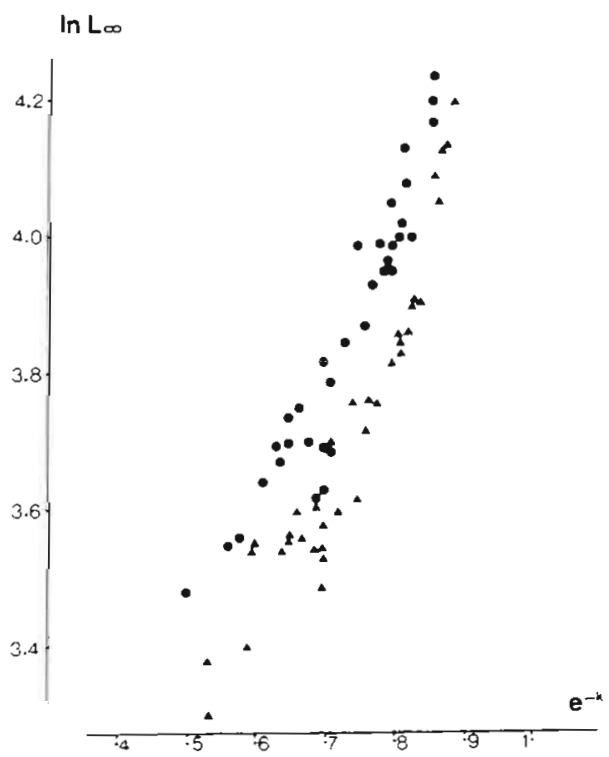

Fig. 7. Cerastoderma edule ( $\bullet$ ) and C. lamarcki (4). The In $L_{\infty}$ to $e^{-K}$ relation for three-year-old cockles; 1975 -year class at Langerak

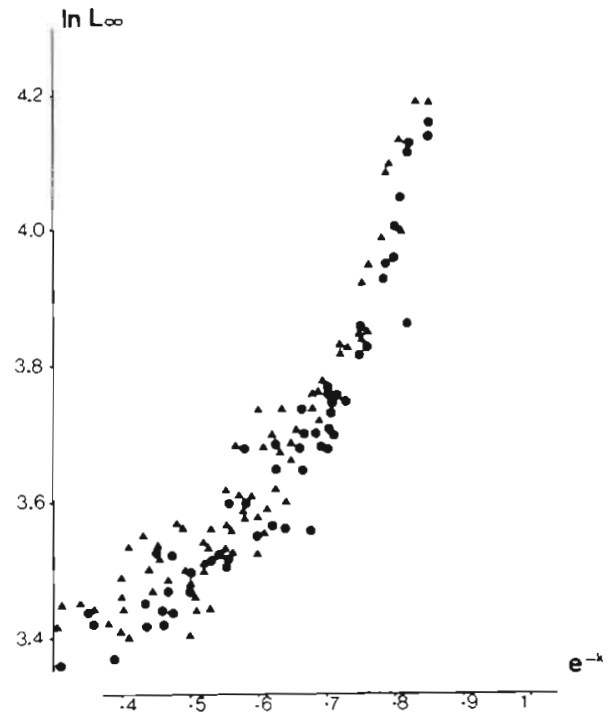

Fig. 8. Cerastoderma edule (•) and C. lamarcki( $\left(\mathbf{)}\right.$. The $\ln L_{\infty}$ to $\mathrm{e}^{-\mathrm{K}}$ relation for three-year-old cockles; 1975-year class at Aggersborg

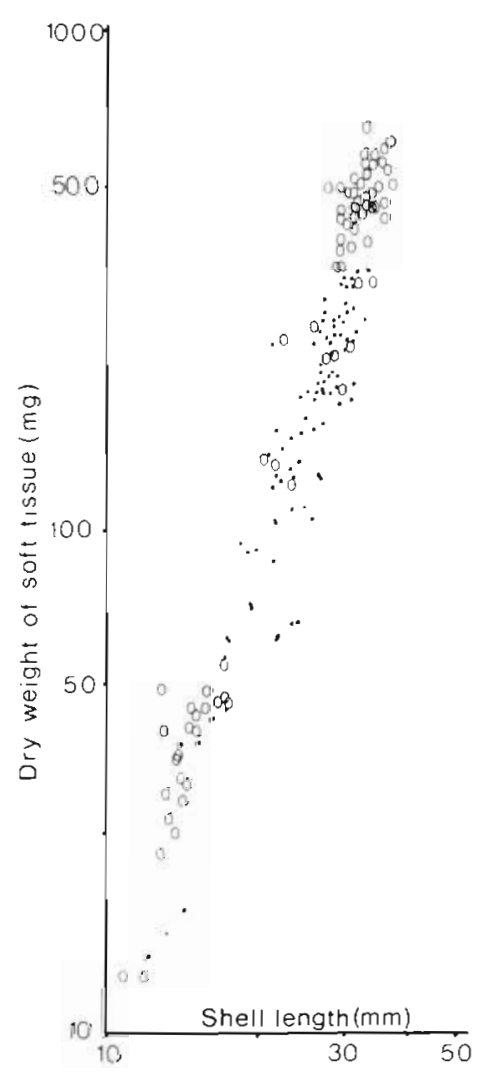

Fig. 9. Cerastoderma edule (o) and C. lamarcki (•). Relation between shell length and dry weight of soft tissue. Double logarithmic scale. Langerak populations, October 1978, O: $C$. edule, $\ln y=3.16( \pm 0.07) \times \ln x-2.12( \pm 0.10), \mathrm{N}=74 .: C$. lamarcki, ln $y=3.07( \pm 0.09) \times \operatorname{lnx}-2.05( \pm 0.11), \mathrm{N}=90$ 
Table 2. Cerastoderma edule and C lamarcki. Observed mean lengths (in $\mathrm{mm}$ ) for three-year-old cockles. 1975 year class. For explanations see Table 1

\begin{tabular}{|c|c|c|c|c|}
\hline Locality & Species & $\begin{array}{c}1_{1} \\
\text { observed }\end{array}$ & $\begin{array}{c}1_{2} \\
\text { observed }\end{array}$ & $\begin{array}{c}1_{3} \\
\text { observed }\end{array}$ \\
\hline Langerak & C. edule & $\begin{array}{c}13.6 \pm 1.9 \\
(45)\end{array}$ & $\begin{array}{c}22.0 \pm 2.0 \\
(45)\end{array}$ & $\begin{array}{c}26.4 \pm 0.7 \\
(45)\end{array}$ \\
\hline Langerak & C. lamarcki & $\begin{array}{c}14.6 \pm 1.8 \\
(51)\end{array}$ & $\begin{array}{c}21.4 \pm 1.7 \\
(51)\end{array}$ & $\begin{array}{c}25.4 \pm 0.9 \\
(51)\end{array}$ \\
\hline Aggersborg & C. edule & $\begin{array}{c}17.2 \pm 1.0 \\
(75)\end{array}$ & $\begin{array}{c}23.7 \pm 1.5 \\
(75)\end{array}$ & $\begin{array}{c}30.0 \pm 2.5 \\
(75)\end{array}$ \\
\hline Aggersborg & C. lamarcki & $\begin{array}{c}15.0 \pm 2.1 \\
(88)\end{array}$ & $\begin{array}{c}23.8 \pm 2.4 \\
(101)\end{array}$ & $\begin{array}{c}29.0 \pm 1.4 \\
(101)\end{array}$ \\
\hline
\end{tabular}

Applied to the observed mean values, the growth model used (Bertalanffy, 1957) gives a fairly good description of the growth rates of both species when using suitable $t_{o}$ values (Figs 3,4). Yet the growth of each does not necessarily fit the model describing the population as a whole (Fig. 10).

Cockle growth during the first growth season is very fast considering the time for larval settlement in July (Boyden, 1971), leaving the young cockles a growth period of only a few months (Figs 3,4). The mean values for $l_{1}, l_{2}$ and $l_{3}$ are smaller for Cerastoderma edule from Langerak sampled after the third growth period, than corresponding values for cockles sampled after the fourth growth period; this indicates selection favouring big $C$. edule at the locality concerned (Table 2). Such selection is probably not due to predation, as no predators preying upon big cockles were found in the areas (Brock, 1979b); hence other factors appear to be involved.

No 1975 data on spawning periods of the two species exist for either of the two localities, but the lengths of the cockles attained at the end of the first growth season hold some information. According to Table 1, Cerastoderma lamarcki mean values are practically equal at the two localities (14.3 $\mathrm{mm}$ and $14.9 \mathrm{~mm})$, and C. edule mean values are different, $13.9 \mathrm{~mm}$ at Langerak and $16.4 \mathrm{~mm}$ at Aggersborg $(\mathrm{P}<0.001)$. These data suggest that $C$. edule spawned earlier than C. lamarcki at Aggersborg. Such displacement in spawning periods in sympatric cockle populations, also found by Boyden (1971) and Rygg (1970), may prevent hybrid formation as suggested by Boyden (1971) and Kingston (1974); in fact no hybrids were found in the investigated material, and none were found in earlier studies (Brock, 1978). Yet a complete overlap in spawning periods has been found in summer 1979 at the Langerak locality (Brock, in prep.). At Langerak, the growth rate of the two species from the $1^{\text {st }}$ to the $4^{\text {th }}$ growth period, demonstrate speciesspecific differences in the response to identical environmental conditions. These differences are stressed by the fact that the growth rate of both species is differently affected by probable differences in the habitat conditions at the two localities. It is remarkable that the environmental conditions at Langerak support fast growth of $C$. edule while, on the other hand, $C$. lamarcki exhibits slower growth at Langerak than at Aggersborg (Table1).

Recent studies (Brock and Kofoed, in prep.) show differences in irrigatory efficiency of the two species at different environmental temperatures. The efficiency of Cerastoderma edule is higher than that of $C$. lamarcki at temperatures below $16{ }^{\circ} \mathrm{C}$, and lower at higher temperatures $\left(16^{\circ}-28^{\circ} \mathrm{C}\right)$. This may explain why C. lamarcki grows at a slower rate at Langerak than at Aggersborg, while $C$. edule grows faster. At Aggersborg the study locality is part of a big low-water area where occasionally the temperature rises considerably in summer. The Langerak locality constitutes part of a slope between the land and the narrow

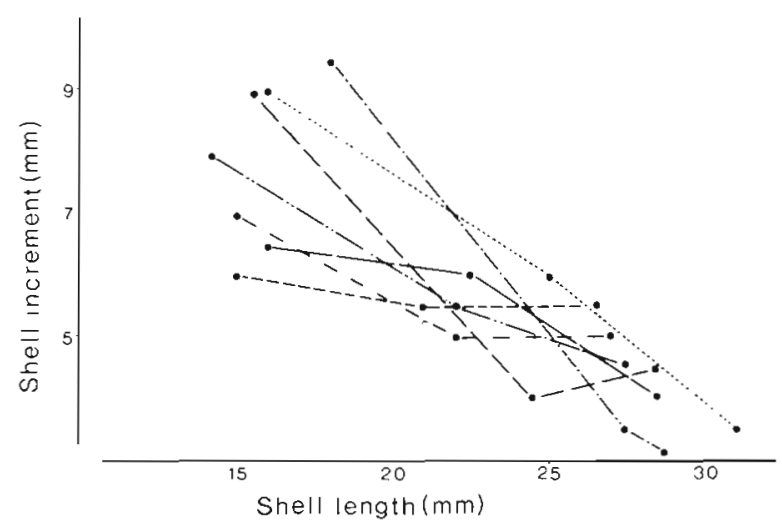

Fig. 10. Cerastoderma edule. Examples of extreme individual growth rates in four-year-old individuals from Aggersborg. Each point represents the length of a cockle related to its length increment from the following year according to Bertalanffy (1957). For each individual, 3 points are inter-connected by lines (left points respresent length at the end of 1975) 
Langerak Strait. The quick water renewal of this area prohibes long periods of extreme temperatures and thus, apparently, does not cause gain in C. lamarcki or stress to $C$. edule at high temperatures. Temperature, and presumably other habitat factors, affect the growth of the two species differentially. Habitat, resources and time constitute the main niche dimensions (Christiansen and Fenchel, 1977). The two species in sympatry grow equally well in one habitat and differently in another; they do respond diffentially to some habitat factors. It can therefore be concluded that the niches of the two species are different.

Acknowledgements. I am grateful to Mrs. Loof Andersen for making polished shell sections and to Dr. F. B. Christiansen and Professor T. Fenchel for valuable discussions and advice.

\section{LITERATURE CITED}

Bertalanffy, L. (1957). Quantitative laws in metabolism and growth. Q. Rev. Biol. 32: 217-231

Boyden, C. R. (1971). A comparative study of the reproductive cycles of the cockles Cerastoderma edule and C. glaucum. J. mar, biol. Ass. U. K. 51: 605-622

Boyden, C. R. (1972). Relationship of size to age in the cockles Cerastoderma edule and $C$. glaucum from the River Crouch Estuary, Essex. J. Conch., London 27: 475-489

Brock, V. (1978). Morphological and biochemical criteria for the separation of Cardium glaucum (Bruguière) from Cardium edule (L.). Ophelia 17: 207-214

Brock, V. (1979a). Habitat selection of two congeneric bivalves, Cardium edule and C. glaucum in sympatric and allopatric populations. Mar. Biol. 54: 149-156

Brock, V. (1979b). Relations between density, settling, and growth for two sympatric cockles. Cardium edule (L.) and C. glaucum (Bruguière). Ophelia (in press)

Brock, V. (in prep.). Immunoelectrophoretic studies of relations between Cerastoderma edule (L.) and populations of C. glaucum/lamarcki (Bruguière/Reeve) from Northern European and Mediterranean localities.
Brock, V., Kofoed, L. (in prep.). Species specific irrigatory efficiency in Cerastoderma edule and C. lamarcki responding to different environmental temperatures.

Christiansen, F., Fenchel, I. (1977). Theories of populations in biological communities, Springer-Verlag, Heidelberg

Eisma, D. (1965). Shell-characteristics of Cardium edule L. as indicators of salinity. Neth. J. Sea Res. 2: 493-540

Hylleberg, J., Brock, V., Jørgensen, F. (1978). Production of sublittoral cockles. Cardium edule $\mathrm{L}$. with emphasis on predation by flounders and sea stars. Nat. Jut. 20: 183-191

Jones, D. S., Thompson, I., Ambrose, V. (1978). Age and growth rate determination for the Atlantic Surf Clam Spisula solidissima (Bivalvia: Mactracea), based on internal growth lines in shell cross-sections. Mar. Biol. 47 : $63-70$

Kingston, P. F. (1974). Studies on the reproductive cockles of Cardium edule and C. glaucum. Mar. Biol. 28: 317-323

Kinne, O. (ed.) (1970). Marine ecology, Vol. I, Environmental factors, Part 1, Wiley, London

Kinne, O. (ed.) (1971). Marine ecology, Vol. I, Environmental factors, Part 2, Wiley, London

Kinne, O. (ed.) (1972). Marine ecology, Vol. I, Environmental factors, Part 3, Wiley, London

Kirstensen, I. (1957). Differences in density and growth in a cockle population in the Dutch Waddensea. Arch. neerl. Zool. 12: 315-453

Kreger, D. (1940). On the ecology of Cardium edule L. Archs. neerl. Zool, 4: 157-200

Muus, R. J. (1967). The fauna of Danish estuaries and lagoons. Meddr Danm. Fisk.-og Havunders. 5: 1-315

Orton, J. H. (1926). On the rate of growth of Cardium edule. Part I. Experimental observations. J. mar. biol. Ass. U. K. 14: 239-279

Riva, A. (1976). Croissance de mollusques bivalves. Bulletin de l'Observatoire de la Mer 3 (Suppl.): 1-177

Rygg, B. (1970). Studies on Cerastoderma edule (L.) and Cerastoderma glaucum (Poiret). Sarsia 43: 65-80

Smidt, E. L. B. (1951). Animal production in the Danish waddensea. Meddr Kommn. Danm. Fisk.-og Havunders. (Ser. Fisk.) 11: 1-51

Thamdrup, H. M. (1935). Beiträge zur Okologie der Wattenfauna auf experimenteller Grundlage. Meddr Danm. Fisk.- og Havunders. (Ser. Fisk.) 10: 1-125 